\title{
Increased faecal mucin sulphatase activity in ulcerative colitis: a potential target for treatment
}

\author{
H H Tsai, A D Dwarakanath, C A Hart, J D Milton, J M Rhodes
}

\begin{abstract}
Colonic mucin is heavily sulphated and it has been shown that enzymatic desulphation by faecal bacterial sulphatases greatly increases its susceptibility to degradation by faecal glycosidases. A possible role for faecal mucin sulphatase in the pathogenesis of inflammatory bowel disease has therefore been explored. Faecal mucin sulphatase activity assayed using ${ }^{35} \mathrm{~S}$ mucin as substrate was increased in ulcerative colitis (median 80.2 units/g pellet weight (range 6.9-1063; 95\% confidence intervals (CI): $45 \cdot 2$ to $293 \cdot 8, \mathrm{n}=22$ ) compared with 11.3 units/g (range 3.0-53.5; 95\% CI: 8.7 to $29 \cdot 8, n=17$ ) in healthy controls $(p<0 \cdot 01)$, where one unit released $1000 \mathrm{dpm}$ free sulphate/hour from ${ }^{35} \mathrm{~S}$ mucin $(1680 \mathrm{dpm} / \mu \mathrm{g})$. Patients with active ulcerative colitis had higher sulphatase activity (median 146; 95\% CI: 98 to 253 units/g, $n=10$ ) than those with inactive ulcerative colitis (median 42.2; CI: 22.5 to $81 \cdot 6$ units $/ g, n=12)(p<0 \cdot 05)$. Longitudinal studies in patients with ulcerative colitis show fluctuations of faecal mucin sulphatase activity corresponding to clinical disease activity in six of seven patients. Faecal mucin sulphatase activity was not significantly increased in Crohn's disease (median 36.6, range 5.7-106.6; 95\% CI: $22 \cdot 9$ to $65 \cdot 3$ units/g, $n=14)$. The bismuth salts, bismuth subcitrate and bismuth subsalicylate were found to inhibit faecal mucin sulphatase activity at concentrations achievable therapeutically. The increased faecal mucin sulphatase activity in ulcerative colitis could be the result of greater intraluminal substrate (mucin) availability leading to bacterial enzyme induction, but would probably result in more rapid degradation of secreted mucin and represents a potential target for treatment.

(Gut 1995; 36: 570-576)
\end{abstract}

Keywords: ulcerative colitis, faecal mucin sulphatase.

H H Tsai

A D Dwarakanath

J D Milton

J M Rhodes

and Medical

Microbiology

C A Hart

University of Liverpool, Liverpool

Correspondence to: Professor J M Rhodes, Department of Medicine, University of Liverpool Liverpool L69 3BX

Accepted for publication 15 July 1994 extracellular enzymes, which allow them to utilise mucin as their sole energy source ${ }^{2}$ and there is a continual balance between the synthesis and secretion of mucus and its breakdown by bacterial glycosidases. ${ }^{34}$ Colonic mucus glycoproteins are heavily sulphated in contrast with mucin from the stomach or small intestine. ${ }^{5}$ This sulphation confers increased charge, which possibly affects the rheological properties of the mucus but, perhaps more significantly, confers resistance to enzymatic degradation by glycosidases. ${ }^{67}$ Sulphation of mucins generally correlates with the presence of bacteria as illustrated by increased mucus sulphation in gastric metaplasia occurring in association with achlorhydria, ${ }^{5}$ in bronchiectasis, and in ileal pouches. ${ }^{8}$ It seems probable that this may represent an important adaptive response to the presence of bacteria. We have recently shown that enzymatic removal of sulphate ester from colonic mucus increases its susceptibility to degradation by faecal glycosidases and we have also described the identification, purification, and characterisation of a faecal mucin sulphatase,${ }^{7}$ the presence of which is probably critical in determining the rate of degradation of secreted mucus in the colon. A hypothesis is therefore proposed that relapse of ulcerative colitis might be related to increased activity of mucin sulphatase and that inhibition of this enzyme could be therapeutically useful. In this study, faecal mucin sulphatase has been assayed in normal subjects and patients with ulcerative colitis and Crohn's disease both in active disease and in remission.

\section{Methods}

\section{PATIENTS AND CONTROL SUBJECTS}

Faecal samples were collected from 17 healthy volunteers, 22 patients with ulcerative colitis, and 14 patients with Crohn's disease, six with ileocolonic disease and eight with ileal disease. Only three of the ulcerative colitis patients were not receiving sulphasalazine. None of the patients or controls had a history of infective diarrhoea in the previous 12 months and none had received antibiotics within the previous month.

Diagnoses of Crohn's disease or ulcerative colitis were based on conventional pathological and radiological criteria. Clinical information was obtained from the patients by history and examination and information recorded onto a standard protocol. The mean stool frequency in the week before obtaining the sample was recorded. In patients with Crohn's disease the disease activity was assessed by the simple Crohn's disease activity index devised by Harvey and Bradshaw. ${ }^{9}$ Disease severity of patients with ulcerative colitis was graded clinically by the scoring method described by Powell-Tuck et al. ${ }^{10}$ All patients with ulcerative colitis had rigid sigmoidoscopy performed for clinical reasons using a disposable Lloyd- 
Davies sigmoidoscope carried out by the same observer. Grading of sigmoidoscopic findings were according to Gomes et al. ${ }^{11}$

The median ages of the normal subjects was 38 years (range 19-52), ulcerative colitis $37 \cdot 5$ years (range 22-78), and Crohn's disease 32.5 years (range 26-65). There was no significant age difference between the three groups $(p=0 \cdot 15$; Kruskal-Wallis one way analysis of variance).

Ethical approval was granted by the Royal Liverpool University Hospital ethical committee.

FAECAL COLLECTION

A morning sample of faeces was collected in sterile containers from the subjects and frozen within two hours of voiding. The samples were kept at $-70^{\circ} \mathrm{C}$ until batch analysis.

\section{SULPHATASE ASSAY METHOD}

\section{Extraction}

Faecal samples of about 1-2 g wet weight were homogenised in $50 \mathrm{ml} 0.05 \mathrm{M}$ TRIS/maleate pH 6.5 in a loose fitting glass homogeniser. The homogenate was centrifuged at $25000 \times g$ for two hours in a refrigerated centrifuge. The supernatant was passed through filters culminating in a 0.2 micron filter to obtain a bacteria free filtrate. Protein analysis was carried out on all samples using the bicinchoninic acid assay. ${ }^{12}$ The centrifuge tubes containing the precipitate were weighed after dessication in an $80^{\circ} \mathrm{C}$ oven and reweighed after washing and drying and the difference taken as the dry weight of the faecal pellet.

\section{Preparation of ${ }^{35} S$ human colonic mucin as substrate}

The method of biological radiolabelling of human colonic mucin has been previously described and validated. ${ }^{7}$ Colonic biopsy specimens were obtained with informed consent from patients undergoing routine colonoscopy who were found to have macroscopically and histologically normal rectal mucosa. The specimens were then cultured in the presence of $\mathrm{Na}_{2}\left[{ }^{35} \mathrm{~S}\right] \mathrm{O}_{4}$ to achieve biological radiolabelling of colonic sulphomucin based on the method of Trier et al. ${ }^{13}$ After 24 hours the mucin was extracted by ultrasonication, desalted, and pooled before purification. The same pooled $\left[{ }^{35} \mathrm{~S}\right.$ ] mucin sample was used as substrate for all the sulphatase assays described here. Mucin was purified by high performance gel filtration. This technique has been shown to produce mucin of high purity without contamination by mannose containing glycoprotein or proteoglycans. ${ }^{1415}$ Sulphatase assay was carried out using ${ }^{35} \mathrm{~S}$ mucin as substrate. Two hundred and fifty $\mu$ l of the stock ${ }^{35} \mathrm{~S}$ mucin $(50000 \mathrm{dpm} / \mathrm{ml})$ were incubated with $250 \mu \mathrm{l}$ of the faecal filtrate in $0.05 \mathrm{M}$ TRIS/maleate $\mathrm{pH}$ 6.5 for 24 hours at $37^{\circ} \mathrm{C}$. The reactants were then applied onto a small gel filtration column (PD-10 G25M, Pharmacia, Milton Keynes,
UK) with exclusion size of 5000 daltons. The intact mucus glycoprotein eluted first in the void volume with clear separation from the liberated sulphate and sulphated monosaccharides or oligosaccharides. Recovery of $\left.{ }^{35} \mathrm{~S}\right]$ from the desalting column averaged $98 \%$ (range $96-99 \%$ ). One $\mathrm{ml}$ of $0 \cdot 1 \mathrm{M}$ barium chloride was added to the pooled low molecular weight fractions (total volume $5 \mathrm{ml}$ ) to separate by precipitation the free sulphate from any sulphated monosaccharides. The excess barium was precipitated by $1 \mathrm{ml}$ of $0 \cdot 1 \mathrm{M}$ potassium sulphate and the precipitate centrifuged and washed before resuspension in scintillant for $\beta$ counting on an LKB 1219 Rackbeta (LKB, Turku, Finland). All assays were controlled against heat inactivated samples.

There is no technique that is sufficiently sensitive to permit accurate estimation of the number of sulphated sugar residues per molecule of mucin in the small samples extracted from biopsy specimens. Enzyme activity cannot therefore be expressed conventionally in terms of micromoles of substrate catalysed. One stock sample of ${ }^{35} \mathrm{~S}$ mucin was used for all the experiments in the study and enzyme activity was defined arbitrarily as: 1 unit is that enzyme activity which releases $1000 \mathrm{dpm}$ of free sulphate per hour at $37^{\circ} \mathrm{C}$. The stock substrate had an activity of $1680 \mathrm{dpm} / \mu \mathrm{g}$ glycoprotein. The mucin sulphatase assay had an interassay coefficient of variation of $8 \cdot 8 \%$.

Faecal mucin sulphatase activity was expressed as units/g faecal pellet weight, units/mg protein content, and as ratio of sulphatase $/ \alpha$ glucosidase activity.

\section{$\alpha$ GLUCOSIDASE ASSAY}

$\alpha$ Glucosidase is an ubiquitous bacterial secreted enzyme, which is not relevant to mucus degradation and that may serve as a useful guide to the total faecal bacterial load. $\alpha$ Glucosidase activity was measured using 4methylumbelliferyl- $\alpha$-D-glucoside (Sigma, Poole, UK) by the method of Potier. ${ }^{16}$ Samples of $0.1 \mathrm{ml}$ were incubated in $0.1 \mathrm{ml}$ of $10 \mathrm{mmol} / 1$ solution of 4-methylumbelliferyl- $\alpha$ $\mathrm{D}$-glucoside and incubated for one hour at $\mathrm{pH}$ $6.5,37^{\circ} \mathrm{C}$ and emission at $450 \mathrm{~nm}$ after excitation at $363 \mathrm{~nm}$ was fluorospectrophotometrically measured.

\section{INHIBITOR ASSAYS}

Bismuth subcitrate (kindly supplied by Brocades Pharma, Liederdorp, Netherlands) at a concentration of $1,2,3,4$, and $5 \mathrm{~g} / 1$ in 0.05 M TRIS/maleate $\mathrm{pH} 6 \cdot 5$, a suspension of bismuth subsalicylate (kindly supplied by Proctor and Gamble, Egham, UK) of $4 \mathrm{~g} / 1$ in $0.05 \mathrm{M}$ TRIS/maleate $\mathrm{pH} 6.5$, dextran sulphate of molecular weights 5000 daltons, 8000 daltons, and 500000 daltons (Sigma, Poole, UK) at a concentration of $0 \cdot 2,0 \cdot 4,0 \cdot 6,0 \cdot 8,1 \cdot 0$, and $5.0 \%$ weight/weight in $0.05 \mathrm{M}$ TRIS/maleate $\mathrm{pH} 6.5$ were each incubated at $37^{\circ} \mathrm{C}$ for 24 hours in the presence of mucin sulphatase purified from a single ulcerative colitis faecal sample and containing $52 \mu \mathrm{g}$ protein $/ \mathrm{ml}$ and 


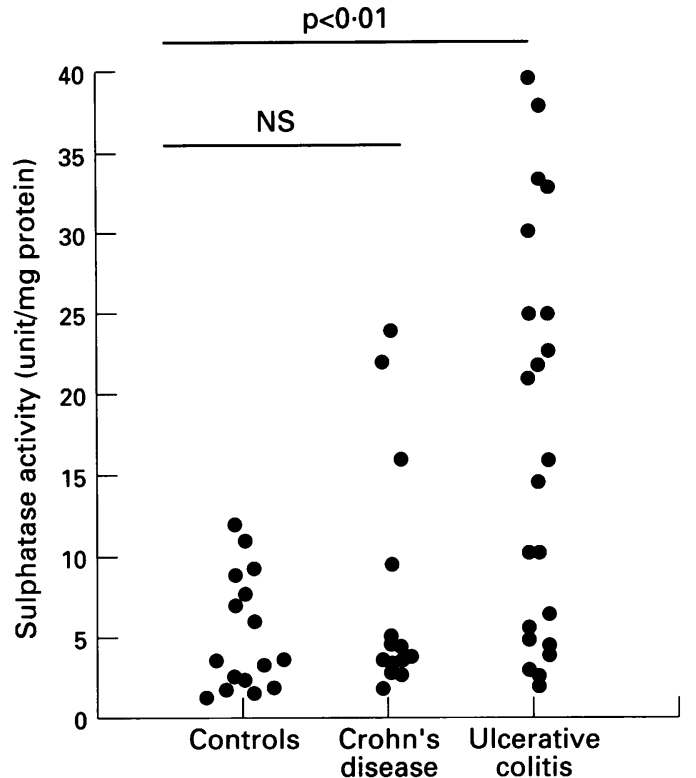

Figure 1: Faecal mucin sulphatase activity expressed per mg protein concentration in normal controls, patients with Crohn's disease, and ulcerative colitis.

$50000 \mathrm{dpm} / \mathrm{ml}^{35} \mathrm{~S}$ mucin. Release of sulphate from the substrate was then assayed as above. In the case of the insoluble bismuth subsalicylate, constant agitation of the reactants was carried out throughout the incubation period.

\section{LEUCOCYTE STUDIES}

Experiments to find out if leucocytes contain mucin desulphating enzymes were performed. Human leucocytes were prepared from $20 \mathrm{ml}$ of venous blood taken from a healthy volunteer collected into lithium-heparin tubes. Erythrocytes were sedimented with $1 \%$ dextran ( $\mathrm{Mr}=70$ 800, Sigma, Poole, UK) in $0.9 \%$ sodium chloride solution for 30 minutes at room temperature. The supernatant was then centrifuged on a lymphocyte separation medium (Flow Laboratories, High Wycombe, $\mathrm{UK}$ ) at $400 \mathrm{~g}$ for 30 minutes. Neutrophils were obtained from the cell pellet and incubated

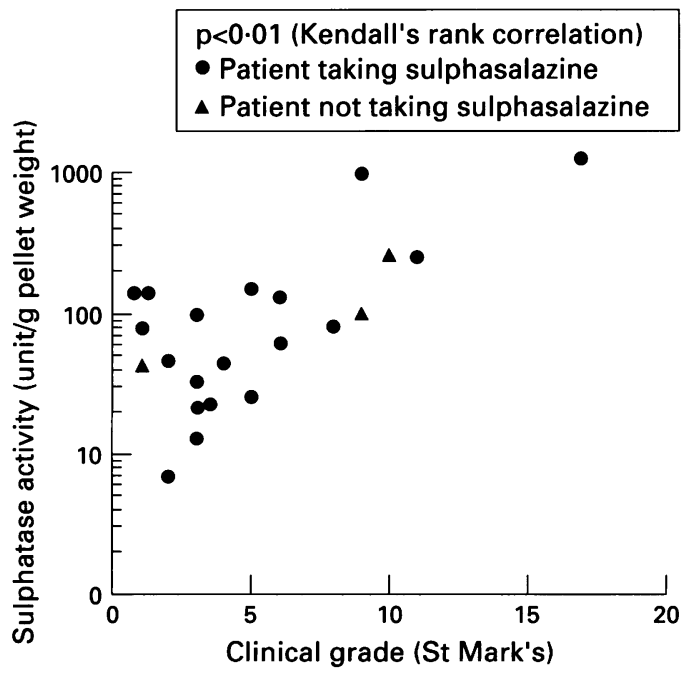

Figure 2: Correlation between clinical grading of ulcerative colitis and faecal mucin sulphatase activity.

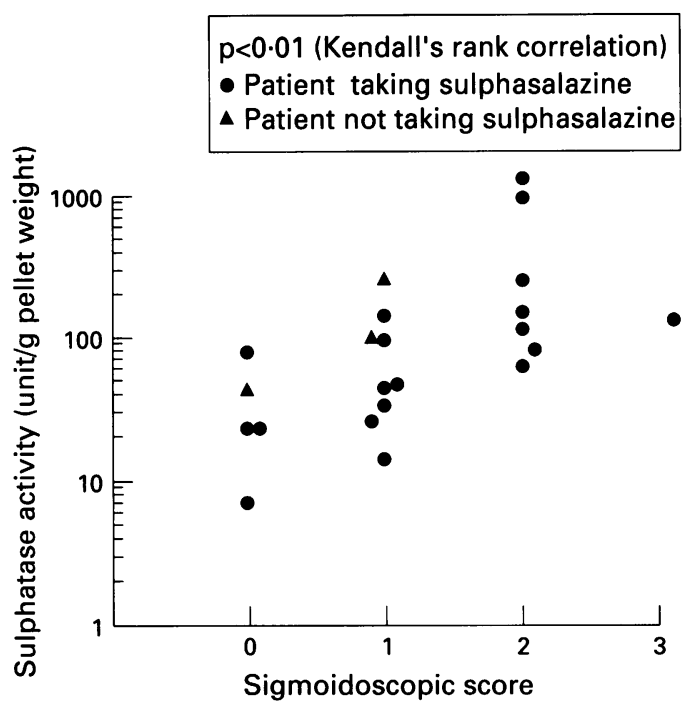

Figure 3: Relation between sigmoidoscopic score and faecal sulphatase activity in patients with ulcerative colitis.

with $0.87 \%$ ammonium chloride to lyse residual erythrocytes. The mononuclear cells were then harvested from the interface. Neutrophil and lymphocyte preparations were then ultrasonicated in $0.05 \mathrm{M}$ TRIS/maleate buffer yielding $23 \mu \mathrm{g}$ protein $/ \mathrm{ml}$ and $4 \mu \mathrm{g} / \mathrm{ml}$ respectively.

A crude faecal extract $(79 \mu \mathrm{g})$, serum $(0 \cdot 1$ $\mathrm{ml}$ ), the polymorphonuclear leucocyte, and mononuclear cell preparations $(2.3 \mu \mathrm{g}$ and 0.4 $\mu \mathrm{g}$ protein respectively) were incubated in the presence of $25000 \mathrm{dpm}{ }^{35} \mathrm{~S}$ mucin for 24 hours and the release of ${ }^{35} \mathrm{~S}$ sulphate assayed as above.

\section{STATISTICAL ANALYSES}

Data comparisons between two groups were performed using Wilcoxon's rank sum test. Multiple group comparisons were performed using the Kruskal-Wallis one way analysis of variance (ANOVA) by ranks. Correlation of sulphatase activity to clinical indices was performed by Kendall's rank correlation for non-parametric data. Two tailed tests of significance were used throughout with $p$ values of $<0.05$ regarded as significant. Ninety five per cent confidence limits are quoted where relevant.

Enzyme inhibitor kinetics were calculated using a method of least squares regression and comparison with models of inhibitor kinetics using the software package Regression (Blackwell Scientific, Oxford, UK) as previously described. ${ }^{17}$

\section{Results}

Faecal sulphatase in inflammatory bowel disease and controls

The median faecal mucin sulphatase activity when expressed in terms of units/g pellet weight was significantly higher in ulcerative colitis $(80 \cdot 2$ (range $6 \cdot 9-1063$; 95\% CI: $45 \cdot 2$ to 293.8 ) units/g, $\mathrm{n}=22$ ) compared with healthy controls $(11.3$ (range $3.0-53.5 ; 95 \%$ CI: 8.7 to 29.8$)$ units/g, $n=17(\mathrm{p}<0.01))$ but 

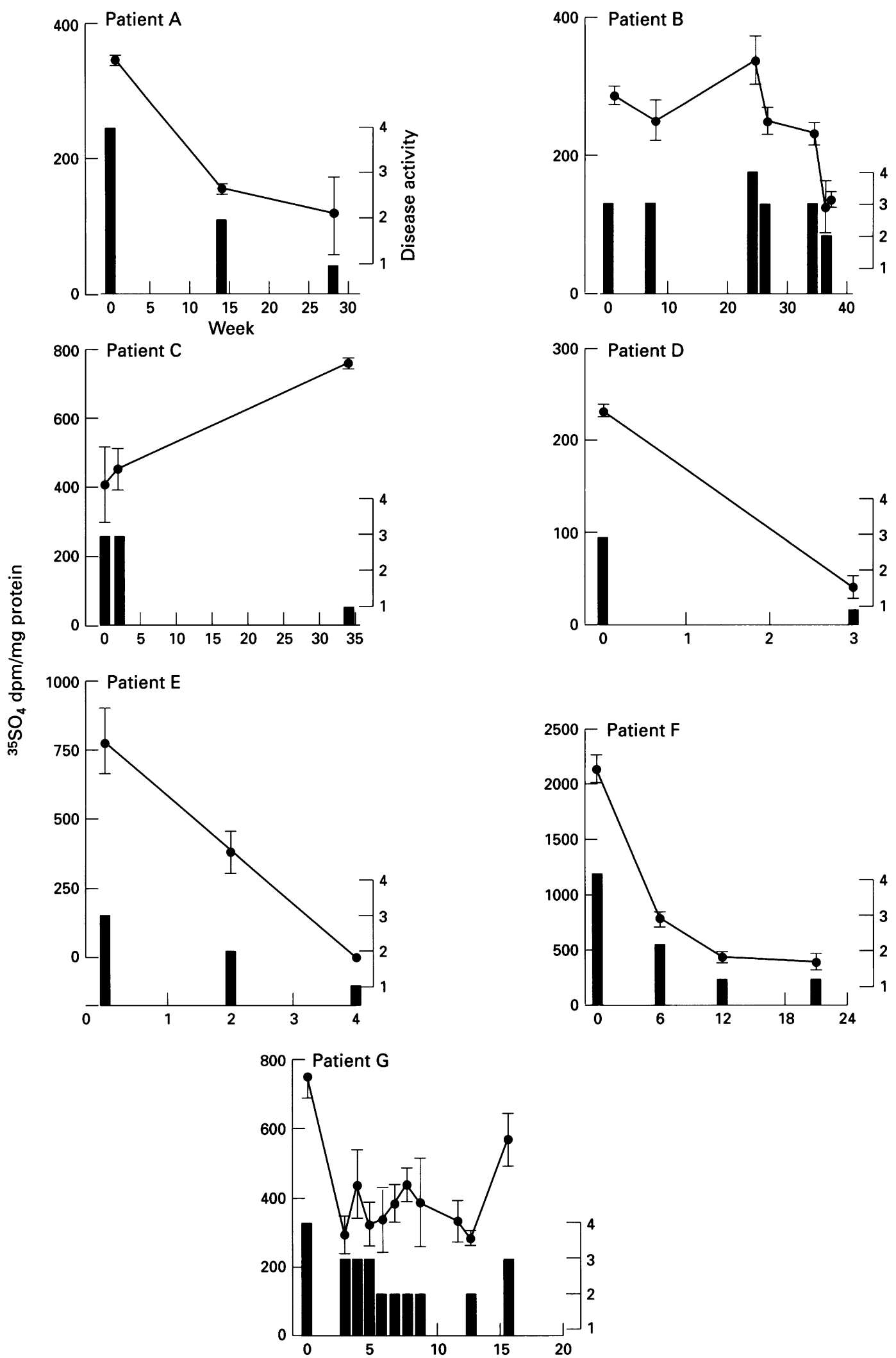

Figure 4: Longitudinal study showing serial faecal mucin sulphatase activity in seven patients in varying degrees of disease activity showing that faecal mucin sulphatase varies with disease activity in all except patient $C$. This study was performed on a different batch of ${ }^{35} \mathrm{~S}$ labelled mucin from the population studies in Figs 1-3.

not significantly changed in Crohn's disease (36.6 (range 5.7-106.6; 95\% CI: $22 \cdot 9-65 \cdot 3$ ) units/g, $\mathrm{n}=14)$. Similarly, when expressed in terms of the protein content of the faecal filtrate, the faecal mucin sulphatase activity was significantly higher in ulcerative colitis; $14 \cdot 2$ units $/ \mathrm{mg}$ (95\% CI: $4 \cdot 2$ to $28 \cdot 8$ ) compared with healthy controls; 3.6 units/mg (95\% CI: 2.4 to
9.3) $(\mathrm{p}<0.01)$ but not significantly raised in Crohn's disease $4 \cdot 1$ units/mg (95\% CI: 3.4 to 9.5 units $/ \mathrm{mg}$ ) (Fig 1). The faecal ratio of sulphatase: $\alpha$ glucosidase activity was also significantly raised in ulcerative colitis (median ratio; $23,95 \% \mathrm{CI}: 15$ to $34, \mathrm{p}<0.01$ ) but not in Crohn's disease (12, 3 to 18) compared with controls $(6,1$ to 11$)$. 

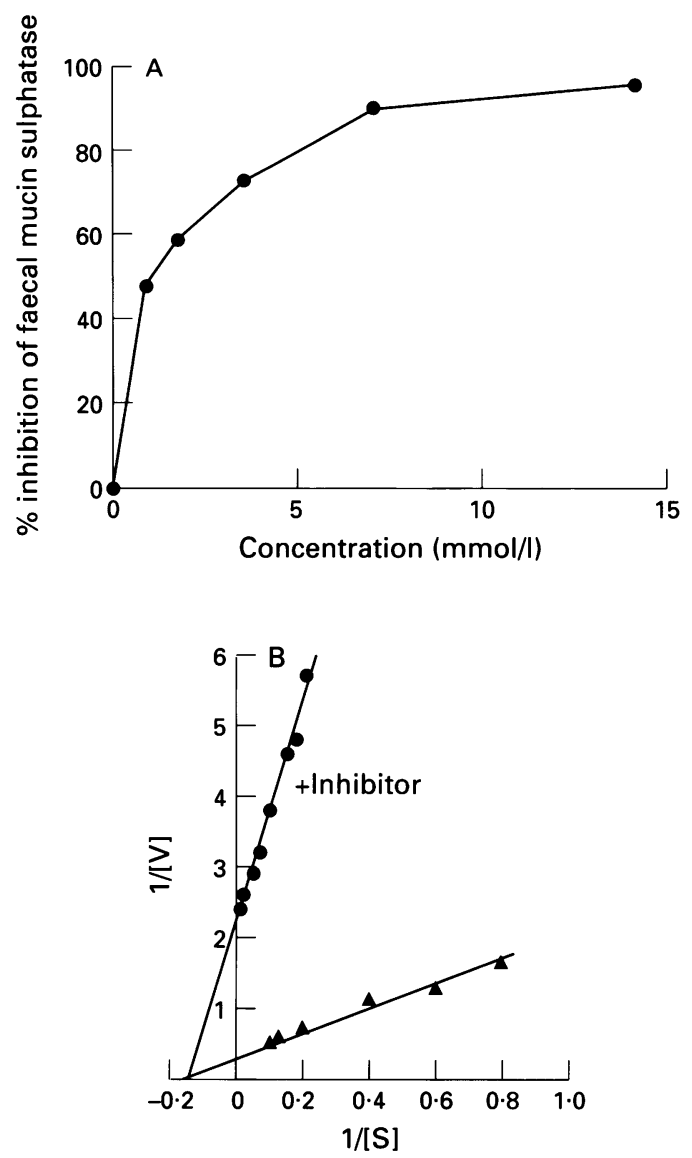

Figure 5: (A) Concentration effect curve of inhibition of bismuth subcitrate on faecal mucin sulphatase; (B) Lineweaver-Burk plot showing non-competitive inhibition of mucin sulphatase by bismuth subcitrate.

\section{Relation between disease activity and faecal} mucin sulphatase activity

Patients with active ulcerative colitis $(n=12)$ had a significantly higher faecal mucin sulphatase activity (median 146 units/g pellet weight, $95 \% \mathrm{CI}$ : 98 to 253 ) compared with those with inactive disease $(\mathrm{n}=10)$ (median 42.2 units/g pellet weight; $95 \%$ CI: 22.5 to $81 \cdot 6)(p<0.05$, Wilcoxon's rank sum test). Faecal sulphatase activity in inactive ulcerative colitis was significantly greater than in healthy controls (median 11.3; 95\% CI: $8 \cdot 7$ to $29.8, \mathrm{n}=17, \mathrm{p}<0.05)$. Sulphatase activity also correlated well with the more detailed St Mark's Hospital clinical scoring described by Powell-Tuck et al ${ }^{10}(t=0.41 ; \mathrm{p}<0.01$, Kendall's rank correlation) (Fig 2). There was a significant positive correlation between sigmoidoscopic score and faecal mucin sulphatase activity (Kendall's $t=0.45, \mathrm{p}<0.01$ ) (Fig 3). Of the ulcerative colitis group studied, only three patients were not receiving sulphasalazine and this was too few for subgroup analysis.

There was no correlation between disease activity and faecal mucin sulphatase activity in Crohn's disease. Faecal sulphatase activity of those with colonic Crohn's disease (median $11 \cdot 0$; range $5 \cdot 7-96$ units/g pellet weight, $n=6$ ) did not differ significantly from those without colonic Crohn's disease (median 68; range 6.9-106 units/g, $n=8$ ), however, the numbers in each group were small.
Longitudinal study

Seven patients with ulcerative colitis were followed up with serial faecal samples analysed for mucin sulphatase activity. Figure 4 shows the faecal sulphatase activity over the time course and disease activity. In six patients the sulphatase activity closely mirrors clinical disease activity.

\section{Effect of leucocyte preparations and serum on ${ }^{35} S$} mucin

The removal of ${ }^{35} \mathrm{~S}$ sulphate groups from ${ }^{35} \mathrm{~S}$ mucin by faecal extract, serum, polymorphonuclear leucocyte, and mononuclear cell preparations compared with buffer alone was assessed. The faecal extract removed $13 \%$ of the sulphate groups but there was negligible mucin sulphatase activity detected in the serum and leucocyte preparations.

\section{Inhibitor studies}

Bismuth subcitrate was assayed for its effects on the sulphatase using nine substrate concentrations $(5,6 \cdot 25,8 \cdot 33,12 \cdot 5,15,25,50$, $100 \times 10^{3} \mathrm{dpm} / \mathrm{ml}$ ) to determine its inhibitor kinetics. Bismuth subcitrate inhibits mucin sulphatase and the kinetic profile of this inhibitor best fits a non-competitive model of enzyme inhibition. The inhibitor constant $\mathrm{K}_{\mathrm{EI}}$ derived from the Dixon plot $^{18}$ was $1.5 \mathrm{mmol} / 1$. The concentration/effect relation was assessed by incubation of sulphatase with five different concentrations of bismuth subcitrate $(0-8 \mathrm{~g} / \mathrm{l}$; 0-14.1 mmol/1) (Fig 5A). Sulphatase activity was inhibited $50 \%$ by bismuth subcitrate (that is, $\left.E_{50}\right) 1.09 \mathrm{mmol} / \mathrm{l}$ and maximal inhibition in excess of $95 \%$ was caused by bismuth subcitrate $13 \mathrm{mmol} / \mathrm{l}$ (Fig 5B).

Bismuth subsalicylate in a suspension of 4 $\mathrm{g} / \mathrm{l}$ inhibited $95 \%$ of mucin sulphatase activity when continuously agitated. Because of the insolubility of the drug, however, it was not possible to determine its $\mathrm{K}_{\mathrm{EI}}$ with any certainty or to ascertain its inhibitor characteristics. The concentration of this suspension is similar to that used therapeutically in bismuth subsalicylate enemas. ${ }^{19}$

Both low molecular weight varieties of sulphated dextrans caused $90 \%$ inhibition of mucin sulphatase activity at a concentration of $5 \% \mathrm{wt} / \mathrm{wt}$. Their inhibition kinetic characteristics best fit a non-competitive model. High molecular weight sulphated dextran inhibits $94 \%$ of mucin sulphatase activity at a concentration of $5 \% \mathrm{wt} / \mathrm{wt}$. Its kinetic characteristics best fit a competitive model.

\section{Discussion}

This study shows that there is increased faecal mucin sulphatase activity in patients with ulcerative colitis. Patients with Crohn's disease also had a slightly raised faecal mucin sulphatase activity but this did not achieve statistical significance. Subgroup analysis showed no difference between Crohn's colitis and small bowel Crohn's disease. This finding is of interest as it makes it less likely that an increase 
in faecal mucin sulphatase merely reflects some non-specific inflammatory activity in the colon. In ulcerative colitis the faecal sulphatase activities were highest in those with active disease. To minimise error resulting from faecal dilution by diarrhoea and increased inflammatory debris in faeces of patients with inflammatory bowel disease we have expressed the results in three ways, as units/g faecal pellet weight, units/mg protein content, and as ratio of sulphatase $/ \alpha$ glycosidase activity. Similar results were obtained using each method. $\alpha$ Glycosidase is expressed by most colonic flora and therefore reflects faecal bacterial load. ${ }^{20}$ The increased sulphatase $/ \alpha$ glucosidase ratio therefore implies a specific increase in sulphatase production or sulphatase producing bacteria rather than a non-specific increase in bacterial activity.

Human serum and leucocytes have been shown not to contain mucin sulphatases. Aryl sulphatases $A$ and $B$ are found in human leucocytes, ${ }^{21}$ but these do not seem to be active on sulphated human colonic mucin.

There may be two possible explanations for the increased faecal sulphatase found in patients with active ulcerative colitis. The first is that an increase in faecal mucin sulphatase activity is secondary to the disease process. If the mucin sulphatase is of bacterial origin, then perturbations of the faecal flora could account for an isolated proliferation of sulphatase producing bacteria. Such perturbations may be as a result of a changed luminal environment such as increased faecal lactate. ${ }^{22}$ Most workers, however, have reported no significant differences in the faecal flora of patients with ulcerative colitis compared with controls. ${ }^{23} 24$

The second possible explanation is that in some patients this increase in faecal sulphatase activity itself contributes to the colitic process by increasing mucin degradation and thus upsetting the balance between mucus production and bacterial degradation. Enzymatic desulphation might well be the rate limiting step in colonic mucin degradation. This could be compounded by mucus changes such as the reduced sulphation that has been shown in cultured mucosal explants from patients with ulcerative colitis ${ }^{25}$ and by the increased susceptibility of ulcerative colitis mucin to degradation by faecal extracts that has been reported by others. ${ }^{26}$ It would still be necessary to postulate an external environmental factor that triggers relapse of colitis, perhaps a gastroenteritic infection. ${ }^{27}$ This explanation is still highly speculative and would require further careful, prospective studies.

The faecal mucin sulphatase has previously been shown to be probably mainly of bacterial origin ${ }^{7}$ particularly Bacteroides spp. ${ }^{28} \mathrm{~A}$ similar mucin sulphatase has also been isolated from a Prevotella strain (RS2) isolated from pig colonic mucosa. ${ }^{29} \mathrm{~A}$ change in the colonic flora by antibiotics might be expected to change the course of ulcerative colitis if this enzyme has a role in the pathogenesis. Intravenous metronidazole ${ }^{30}$ and oral vancomycin ${ }^{31}$ have so far not been shown to be effective treatment in ulcerative colitis. Oral tobramycin has been shown in one study, however, to produce promising results when given in combination with corticosteroids. ${ }^{32}$ None of these antibiotic regimens are capable of sterilising the colon ${ }^{20}$ but permit different bacterial species to proliferate preferentially. The possible change in faecal mucin sulphatase activity by antibiotics would clearly require further study.

Previous assessment of faecal sulphatase activity in inflammatory bowel disease has been attempted using high iron diamine histochemical staining as a semi-quantitative estimate of mucin sulphation. ${ }^{33}$ This showed that high iron diamine staining was often lost after treatment of rectal mucosal sections with bacteria free faecal extracts but failed to show any significant increase in this effect in ulcerative colitis. It is probable, however, that high iron diamine staining, which is dependent on charge, may be affected by other changes in mucin such as sialylation. ${ }^{34}$ This is supported by the discrepancy between the pattern of staining seen in the normal rectum, where high iron diamine positivity is confined to the lower crypts in contrast with autoradiography after mucosal culture in the presence of ${ }^{35} \mathrm{SO}_{4}$, which shows incorporation of sulphate into mucus, although not necessarily into mucin, throughout the crypts. ${ }^{35}$

Increased faecal sulphatase activity has also been shown in ulcerative colitis using lactilol 6 -sulphate as substrate ${ }^{26}$ but it is probable that the enzymes that act on this substrate are different from those that act on the sulphated residues in mucin. ${ }^{29}$

Longitudinal studies showed that mucin sulphatase activity mirrored relapse and remission of the disease in six of seven patients in this study. Whether or not this increase in sulphatase activity is the cause or the result of the relapse, it is likely to contribute to the perpetuation of the disease by increasing mucin depletion and leaving the mucosa vulnerable to damage by toxic colonic contents.

The bacterial sulphatase, because of its critical role in determining the rate of degradation of secreted mucus, is a primary target for the development of new therapeutic agents for colitis. The sulphated dextrans are not appropriate for intraluminal treatment, because like other sulphated polysaccharides (for example, carrageenan), they tend to cause colitis. ${ }^{36}$ The explanation for the difference between the competitive inhibition seen with high molecular weight dextran and the non-competitive inhibition with lower molecular weight dextrans is unclear; but it is possible that the higher molecular weight dextrans mimic sulphated mucin and so are an alternative substrate for the sulphatase. Further experiments with appropriately labelled dextran sulphate would be required to assess this. Bismuth salts like other heavy metals, act as non-specific enzyme inhibitors, and are shown here to be effective sulphatase inhibitors and have been shown to have promising effects when used in patients with corticosteroid resistant colitis. ${ }^{19}$

Faecal mucin sulphatase is probably critical in determining the rate of degradation of secreted mucus and the increased concentrations in ulcerative colitis, whether a primary 
phenomenon or secondary to disease, are probably relevant to the reduction in mucus gel thickness that has recently been reported. ${ }^{37}$ Conversely, the comparative lack of increased faecal sulphatase in Crohn's disease is in keeping with the comparatively thick mucus layer ${ }^{37}$ and the comparative lack of histological mucus depletion ${ }^{38}$ that help distinguish Crohn's disease from ulcerative colitis.

HHT and ADD were supported by grants from the National Association for Colitis and Crohn's Disease and the British Digestive Foundation.

1 Creeth JM. Constituents of mucus and their separation. $\mathrm{Br}$ Med Bull 1978; 34: 17-24.

2 Miller RS, Hoskins LC. Mucin degradation in human colon ecosystems. Fecal population densities of mucin-degrading bacteria estimated by a 'most probable number' method. Gastroenterology 1981; 81: 759-65.

3 Corfield AP, Williams AJK, Clamp JR, Wagner SA, Mountford RA. Degradation by bacterial enzymes of colonic mucus from normal subjects and patients with inflammatory bowel disease: the role of sialic acid metabolism and the detection of a novel esterase. Clin Sci 1988; 74: 71-8.

4 Hoskins LC, Augustines M, McKee WB, Boulding ET, Kriaris M, Neidermeyer G. Mucin degradation in human Kriaris $M$, Neidermeyer $G$. Mucin degradation in human colon ecosystems. Isolation and properties of faecal strains that degrade $\mathrm{ABH}$ blood group antigens and oligosaccharides from

944-53.
Filipe MI. Mucins in the human gastrointestinal epithelium: a review. Investigative Cell Pathology 1979; 2: 195-216.

6 Mian N, Anderson CE, Kent PW. Effect of O-sulphated groups in lactose and $\mathrm{N}$-acetyl neuraminyl-lactose on their enzymic hydrolysis. Biochem $f$ 1979; 181: 387-99.

7 Tsai HH, Sunderland D, Gibson G, Hart CA, Rhodes JM. A novel mucin sulphatase from human faeces: its identification, purification and characterisation. Clin Sci 1992; 82: 447-54.

8 de Silva HJ, Millard PR, Kettlewell M, Mortensen NJ, Prince C, Jewell DP. Mucosal characteristics of pelvic ileal Prince C, Jewell DP. Mucosal
pouches. Gut 1991; 32: 61-5.

9 Harvey RF, Bradshaw JM. A simple index of Crohn's disease activity. Lancet 1980; i: 514.

10 Powell-Tuck J, Brown RL, Lennard-Jones JE. A comparison of oral prednisolone given as single or multiple doses for active proctocolitis. Scand f Gastroenterol 1978; 13: 833-7.

11 Gomes P, Du Boulay C, Smith CL, Holdstock G. Relationship between disease activity indices and colonoscopic findings in patients with colonic inflammatory bowel disease. Gut 1986; 27: 92-5.

12 Smith PK, Krohn RI, Hermanson GT, Mallie AK, Gartner $\mathrm{FH}$, Provenzano MD, et al. Measurement of protein using Ficinchoninic acid. Anal Biochem 1985; 150: 76-85.

13 Trier JS. Organ-culture methods in the study of gastrointestinal-mucosal function and development. $N$ Engl $f$ Med 1976; 295: 150-5.

14 Raouf AH, Parker N, Iddon D, Ryder S, Langdon-Brown $\mathrm{B}$, Milton JD, et al. Ion-exchange chromatography of purified colonic mucus glycoproteins in inflammatory bowel disease: absence of a selective subclass defect. Gut 1991; 32: 1139-45.

15 Parker N, Raouf AH, Ryder SD, Finnie IA, Tsai HH, Milton JD, et al. High performance gel filtration using a monodisperse agarose column as a one-step method for purifying mucus glycoprotein. Biomed Chromatogr 1993; 7: 68-74.
16 Potier M, Mamelli L, Belise M, Dallaire L, Melanchon SB. Fluorometric assay of neuraminidase with a sodium (4methylumbelliferyl- $\alpha-D-N$-acetylneuraminate) substrate. Anal Biochem 1978; 94: 287-96.

17 Tsai HH. Statistical analyses of enzyme inhibitor kinetics: a hierarchical model-dependent method. Biochem Int 1991; 23: 75-81.

18 Dixon M, Webb EC, Thorne CJR, Tipton KF. Enzymes. 3rd ed. London: Longman, 1979: 164-82.

19 Ryder SD, Walker RJ, Jones H, Rhodes JM. Rectal bismuth subsalicylate as therapy for ulcerative colitis. Aliment Pharmacol Ther 1990; 4: 333-8.

20 Hawksworth G, Drasar BS, Hill MJ. Intestinal bacteria and the hydrolysis of glycosidic bonds. 7 Med Microbiol 1971; 4: 451-9.

21 Ray AB. Sulfatases, lysosomes and faeces. Aust $\mathcal{f}$ Exp Biol Med Sci 1976; 54: 111 .

22 Roediger WLW. What sequence of pathogenic events leads to acute ulcerative colitis. Dis Colon Rectum 1988; 31: 482-7.

23 van der Wiel-Korstanje JAA, Winkler $\mathrm{K}$. The faecal flora of ulcerative colitis. $\mathcal{f}$ Med Microbiol 1988; 8: 491-501.

24 Gorbach S, Nahas L, Plant A, Weinstein L, Peterson J, Levitan R. Studies of intestinal microflora. V. Fecal microbiol ecology in ulcerative colitis and Crohn's disease: its relationship to severity of disease and chemotherapy. Gastroenterology 1968; 54: 575-87.

25 Raouf AH, Tsai HH, Parker J, Hoffman RJ, Walker RJ, Rhodes JM. Sulphation of colonic mucin in ulcerative colitis and Crohn's disease. Clin Sci 1992; 83: 623-6.

26 Corfield AP, Wagner SA, O'Donnell LJD, Durdey $P$, Mountford RA, Clamp JR. The roles of enteric bacterial sialidase, sialate $O$-acetyl esterase and glycosulfatase in the degradation of human colonic mucin. Glycoconj $\mathfrak{f}$ 1993; 10: 72-81.

27 Felsen J, Wolarsky W. Acute and chronic bacillary dysentry and chronic ulcerative colitis. $\mathcal{J} A M A$ 1953; 153: 1069-72.

28 Tsai HH, Hart CA, Rhodes JM. Production of mucin degrading sulphatase and glycosidases by Bacteroides thetaiotaomicron. Letters in Applied Microbiology 1991; 13: 97-101.

29 Roberton AM, McKenzie CG, Sharfe N, Stubbs LB. A glycosulphatase that removes sulphate from mucus glycoprotein. Biochem f 1993; 293: 683-9.

30 Chapman RW, Selby WS, Jewell DP. Controlled trial of intravenous metronidazole as an adjunct to corticostroids in severe ulcerative colitis. Gut 1986; 27: 1210-2.

31 Dickinson RJ, O'Connor HJ, Pinder I, Hamilton I, Johnson D. A controlled trial or oral vancomycin as adjunctive treatment in acute exacerbation of idiopathic colitis. Gut treatment in acute

32 Burke DA, Axon ATR, Clayden SA, Dixon MF, Johnston $D$, Lacey RW. The efficacy of tobramycin in the treatment of ulcerative colitis. Aliment Pharmacol Ther 1990; 4: 123-9.

33 Rhodes JM, Black RR, Gallimore R, Savage A. Histochemical demonstration of desialation and desulphation of normal and inflammatory bowel disease rectal mucus by faecal extracts. Gut $1985 ; 26$ : $1312-8$.

34 Spicer SS. Diamine methods for differentiating mucosubstances histochemically. F Histochem Cytochem 1965; 13: 599-603.

35 Filipe M. ${ }^{32}$ Sulphur uptake in the mucosa adjacent to carcinoma of large intestine. Histochem $\mathcal{7} 1971 ; 3: 27-35$.

36 Onderdonk AB, Hermos JA, Dzink JL, Bartlett JG. Protective effect of metronidazole in experimental ulcerative colitis. Gastroenterology 1978; 74: 521-6.

37 Pullan RD, Thomas GAO, Rhodes M, Newcombe RG, Williams GT, Allen A, et al. Thickness of adherent mucus gel on colonic mucosa in humans and its relevance to colitis. Gut 1994; 35: 353-7.

38 Filipe MI, Dawson I. The diagnostic value of mucosubstances in rectal biopsies from patients with ulcerative colitis and Crohn's disease. Gut 1970; 11: 229-34. 